Çaml, A. Y. (2020). Yeni bir toplum kuram dinamiği: pratik- rasyonellik. KOCATEPEİIBF Dergisi, Haziran 2020, 22(1), 14-27.

\title{
YENİ BİR TOPLUM KURAM DİNAMİĞİ: PRATİK-RASYONELLİK
}

\section{AHMET YAVUZ CAMLI ${ }^{1}$}

ÖZ

Rasyonellik genel bir tabirle günümüzde toplumsal yapının ve alt sistemlerin üzerine kurulu olduğu dinamiklerin oluşturduğu temel varsayımlardan biridir. Çıkarılan yasalar, benimsenen politikalar, ekonomik ve mali yöntemler gibi unsurlara ilişkin tüm kuramsal ve pratik işleyiş rasyonel ilkelere dayalıdır. Mikro açıdan bakıldığında ise rasyonellik bireylerin eylemde bulunurken çıkarlarını maksimize edip hedeflerine en kolay ve en az maliyetle ulaşması demektir.

Max Weber'in geliştirdiği rasyonellik teorisi çok boyutlu bir yapıya sahiptir. 0, Batı toplumlarına atfettiği rasyonelleşme teorisini iki temel rasyonellik modeli üzerine inşa eder. Bunlar modern kapitalizmin ortaya çıkışına zemin hazırlayan pratik-rasyonellik ile olgunlaşması ve kurumsallaşmasını sağlayan amaçsal-rasyonelliktir. Amaçrasyonelliğin günümüzde bütün sistemleri domine etmesi; değer alanlarının ve birey, kurum ve toplumların pratikrasyonellik rehberliğinde yeniden dizaynını gerektirir. Bu rasyonellik türü günümüz insanının maddi çıkarlarını koruyup manevi dünyasını da ideal olana yükselterek rasyonel toplum özleminin gerçekleștirilmesini sağlayabilir.

$\mathrm{Bu}$ bakımdan çalışmada rasyonellik kavramı, toplumsal eylemin tasnifi ve rasyonellik çeşitleri kısaca izah edilip Weber'le birlikte Alman düşünce hayatının en önemli isimlerinden Kant'ın referanslarına başvurularak pratikrasyonellik olgusu ortaya çıkarılmaya çalışılacaktır.

Anahtar Kelimeler: Rasyonellik, Pratik-Rasyonellik, Kapitalizm, Weber, Kant.

JEL Kodları: A14, B00, N00.

\section{A NEW SOCIETY THEORY DYNAMICS: PRACTICAL-RATIONALISM}

\begin{abstract}
In general terms, rationality is one of the basic assumptions of the dynamics upon which social structure and subsystems are built. All the theoretical and practical procedures related to the enacted laws, policies adopted, economic and financial methods are based on rational principles. From a micro perspective, rationality means that individuals can maximize their interests while acting and achieve their goals with the easiest and least cost.

Max Weber's theory of rationality has a multidimensional structure. He bases his theory of rationalization on Western societies on two basic models of rationality. These are practical-rationality that prepares the ground for the emergence of modern capitalism and purposeful-rationalism that enables it to mature and institutionalize. Purposeful-rationality to dominates all systems today; it requires redesign of value fields and individuals, institutions and societies under the guidance of practical-rationality. This type of rationality can ensure the longing of rational society by protecting the material interests of today's people and raising their spiritual world to the ideal.

From this perspective, the concept of rationality, the classification of social action and the types of rationality will be explained briefly, then referring to Weber's and Kant's references to reveal the phenomenon of practical-rationality in this study.
\end{abstract}

Keywords: Rationality, Practical-Rationality, Capitalism, Weber, Kant.

JEL Codes: A14, B00, N00.

\footnotetext{
${ }^{1}$ Dr. Öğr. Üyesi. Manisa Celal Bayar Üniversitesi, Kula Meslek Yüksek Okulu, Yönetim ve Organizasyon Bölümü, ahmetyavuz.camli@cbu.edu.tr- ORCID: 0000-0002-0746-9755
} 


\section{GíRiş}

Modern çă̆ bütün olumlu ve olumsuz getirileriyle beraber insanoğluna yeni bir hayat formatı sunar. Yenilikler ve gelişmeler birey, firma ve devlet nazarındaki tüm ilişki ve faaliyetlerin yeniden organizasyonuna yol açar. Baş döndüren teknolojik ilerlemeler, tabii olarak ekonomi ve siyaset gibi alanların da şekillenmesinde etkin rol oynar. Amaç-rasyonel yapıya sahip post-modern dünyada teknoloji ve birbirine bağlı olarak ekonomi ve finans sistemleri her geçen gün hiç olmadığı kadar ilerlemesine rağmen iktidar sarhoşluğunun, toplumsal yozlaşmanın, adaletsizliğin, iletişim kopukluğunun, ırksal ve dinsel ayrımcllığın, zengin-fakir uçurumunun, suç oranlarının, bencilliğin, hazcılığın ve savaşların hüküm sürdüğü de bir gerçektir.

Tüm bu süreçte toplumlar çeşitli krizlere maruz kalır. Özellikle kapitalist formasyonun kişisel ve kamu alanlarında otorite kurması sistem kaynaklı problemleri gün yüzüne çıkarır. Dolayısıyla 19. yüzyılın sonlarından itibaren modernizme ya da kapitalizme karşıt olarak 'ideal' toplum, birey, firma, piyasa gibi özlemler gündeme gelir. Birçok siyaset teorisyeni, sosyolog, düşünür, entelektüel ve toplum bilimci modernizmin problemlerine çözüm üretmeye çalışır. Toplum kuramcıların en önemlileri arasında olan Max Weber'in pratik-rasyonellik kavramı da bu şartlarda ileri sürülebilecek bir modeldir. Pratikrasyonellik olgusu Weberyen sosyolojinin bir sacayağını oluşturmasına rağmen gerek Weber gerekse onun takipçileri tarafından hak ettiği değeri bulamaz. Dahası karşı kutupta yer alan ve modern kapitalizmi temsil eden amaç-rasyonelliğin gölgesinde kalır. Weber'in pratik-rasyonellik olgusunun, günümüzde değer alanlarının ve bireysel-toplumsal eylemlerin yeniden dizayn edilmesindeki rolünün ortaya çıkarılması son derece önemlidir.

$\mathrm{Bu}$ açıdan rasyonellik olgusunun günümüz toplumlarını içine sürüklediği konum ile pratik-rasyonellik anlayışının ulaşmak istediği nokta belirli ilkeler eşliğinde aktarılacaktır. Başka bir deyişle 'olan' ile 'olması gereken'i resmetmeye çalışmak bu çalışmanın esas gayesini ifade eder. Ayrıca iyiyi sadece iyi olduğu için yapmanın, akılcılı̆ı̆ın yanında ahlaklı ve erdemli olmanın ekonomik, sosyal ve kültürel hayatı nasıl etkileyebileceği de tartışılacaktır. Bu doğrultuda Weber'e Batı düşünce dünyasının önemli isimlerinden olan Kant eşlik edecektir. Weber'in sosyolojisine sağlam bir temel inşa eden Kant insanın iyiyi herhangi bir çıkar olmadan sadece iyi olduğu için istemesi gerektiğini öne sürer. Aynı şekilde bireyler eylemlerini adalet, ahlak, erdem gibi değerlere göre șekillendirmelidir, bu durum bireylerin salt pratik akılla hareket etmelerini sağlar.

Aşağıda öncelikle Weberyen sosyolojiye göre amaç-rasyonel zihniyetin yol açtığı krizlere kısaca değinilecek, ardından Weber ve Kant'ın temel eserlerinden yola çıkılıp düşünce dünyalarına detaylı bir şekilde temas edilecektir.

\section{AMAÇSAL-RASYONELLÍĞİN SONUÇLARI}

Amaçsal-rasyonelliğin ya da daha bilinen bir ifade ile modern kapitalizmin, geniş kapsamlı bir organizasyon olarak dini, siyasi, hukuki, ekonomik, toplumsal ve kültürel pek çok alanı etkilediği görülür. Modern toplumda doğup amaç-rasyonelliğin veya daha acımasız olarak araç-rasyonelliğin sonuçlarını tecrübe etmiş Batılı düşünürlerin modern kapitalizmi hiç çekinmeden eleştirdikleri bilinir. Max Weber de kendi içinde çelişse de kapitalizmi eleştiren başlıca düşünürler arasındadır.

Weber, modern kapitalizm organizasyonunu benimseyen Batılı toplumlarda bireyin anlam kaybı ve özgürlük kaybına maruz kaldığını belirtir. Birey, hayatı anlamlandırmaktan uzak bir şekilde içsel dünyasında meydana gelen tahribata karşı koyacak değerleri kaybetmiş haldedir. Manevi olarak yapayalnız hisseder, varoluşunun sebep ve sonuçlarını kavrayamaz, kendinin değersiz bir 'şey'e dönüşünü çaresizce izler. Kişi, kapitalist organizasyon içinde insani varlığını unutmuş şekilde kendini bir meta, bir şey gibi görür. 0, artık çarkın bir parçasıdır. Weber bu durumu özgürlük kaybı olarak tanımlar. Batılı birey, özgürce düşünemez, özgürce davranamaz, mesleğini özgürce yapamaz, kendi ürettiği ürünü bile özgürce sahiplenemez. Fabrikasyon sisteminde insan bir amaç olmaktan çıkıp araç konumuna düşürülür. Politik sistemde bürokrasinin, sosyo-ekonomik hayatta kapitalizmin bünyesindeki dinamikler, sosyokültürel hayatta birer dinamite dönüşerek modern hayatı demir kafese çevirir. Batılı bireyler bu anlamsız ve soğuk demir kafesin içinde doğup yaşamaya mahkumdur. Ayrıca rasyonelleşme sürecinde bir sürü yeni put icat edilir ki Weber bu süreci yeni-putperestlik olarak ifade eder. Eskiden insanlar bir Tanrı'ya taparken modern hayatı binlerce Tanrı'nın işgal ettiğini söyler. Bu süreçte tüm değer alanları birbirinden ayrışır, her bir sistem kendi ilke ve kurallarıyla hareket ederek dini ve kültürel yapının birleștirici özelliğinden kendilerini azat ederler. Weber'e göre insanlar artık büyüsü bozulmuş bir dünyada yaşamak, ruhsuz uzmanlar ve hissiz hedonistlerin (kapitalist burjuva sınıfi) egemenliğine boyun eğmek zorundadır. 0 , amaçsal-rasyonelliğin veya modern kapitalizmin Batı toplumlarında meydana getirdiği bu ağır tahribatı The Protestant Ethic and the Spirit of Capitalism adlı eserinde detaylı bir şekilde ele alır (Weber, 1950a: 155-181). 
Weber bir yandan bu değersel erezyonu eleştirirken diğer yandan amaçsal-rasyonel anlayışın gelişmesini destekleyen bir düşünceye sahiptir. Bu husus Weberyen paradigmanın büyük çelişkisini oluşturur. Aşağıda hem Weber'in sosyolojisindeki boşluk doldurulmaya çalıșlacak hem de amaçsal-rasyonelliğin ortaya çıkardığı sosyo-kültürel problemlere yine Weberyen sosyolojiden üretilen 'pratik-rasyonellik' olgusuyla çözüm aranacaktır.

\section{MAX WEBER'DE PRATIK-RASYONELLIKK}

\subsection{Rasyonelleşme Kavramı ve Rasyonelleşme Teorisi}

Weber'in rasyonelleşme argümanı, ardından gelen nesillere muazzam bir malzeme birikimi sunar. Onun ortaya koyduğu teori araştırmacıların düşünce dünyalarında farklı pencereler açar. En önemli klasik toplumsal gelişme kuramlarından birini ortaya koyan Weber'in eserlerine istinaden akademik dünyada rasyonelliğe dair pek çok tanım zikredilir.

Weber'e göre rasyonelleşme sade bir ifadeyle bireyin bütün seçim, eylem ve kararlarında rasyonel ilkelere göre hareket etmesidir (Weber, 1950a:24). Birey ihtiyacını en iyi şekilde karşılamak amacıyla amaç veya amaçlar belirler, amaç veya amaçlara ulaşmasını temin edecek en kolay ve en az maliyetli araç ya da araçları araştırır, yaptığı tercihlerin sonuçlarını öngörür ve ortaya çıkabilecek beklenmedik durumlara karşı hazırlıklı olur.

Diğer bir deyişle rasyonelleşme olgusu; aklın belirli bir eylemi bugün için mevcut bulunan boyutlarıyla, öncesini ve sonrasını da göz önünde bulundurarak kontrol etmesi, yönlendirmesi ve nihayete erdirmesi durumudur (Weber, 1950a:75; Özer, 2010:14). Geniş yelpazede ele alındığında ise aklın ekonomi, siyaset, bilim, hukuk, yargı, maliye, askeriye gibi değer alanlarının organizasyonunda, ilkelerinin tespitinde, işlerlik kazanmasında, denetlenmesinde vb. aşamalarda etkin bir şekilde faaliyette olması halidir (Weber, 1950a:26). O halde rasyonellik cephesinde hesaplanabilirlik, denetlenebilirlik, mantıksallık, bilimsellik, bilinçlilik, evrensellik ve sistematiklik gibi değerlerin yattı̆̆ı söylenebilir.

Weber'in rasyonellik kavramını daha iyi anlamak için onun rasyonelleşme çeşitlerine önsöz niteliğinde olan toplumsal eylemleri nasıl kategorize ettiğine göz atmak faydalı olacaktır.

\subsubsection{Toplumsal Eylem İdeal Tipleri}

Weber dört ana toplumsal eylem ideal tipi öne sürer, bunların evrensellik özelliği olduğunu belirtir ve bu eylemsel tasnif üzerinden rasyonelleșme teorisinin can alıcı noktalarından birini yürütür. Ayrıca toplumsal eylemlerin tarihsel süreçte ve farklı çerçevelerde daha başka ideal tiplerinin geliştirilebileceğini de belirtir. Böylece irrasyonel bir uç noktasına rasyonel bir anlama ile varllabileceğini düşünür. Buradan hareketle Weber toplumsal eylemleri rasyonel eylemler ve irrasyonel eylemler olarak iki ana grupta ele alır. Rasyonel eylemler, amaç-rasyonel eylem ve değer-rasyonel eylem olarak ikiye ayrılır. İrrasyonel eylemler ise duygusal eylem ve geleneksel eylem olarak iyi kategoriye ayrllır.

Bireyin kendi çıarını düşünerek rasyonel verili bir amacı rasyonel araçlarla gerçekleştirmesine amaçrasyonel eylem, karar veya eylem aşamasında değerler ıșığında hareket etmesine değer-rasyonel eylem denir. Bu sosyal eylem tipleri sonraki bölümde ayrıntılı șekilde işlenecektir.

İrrasyonellik bünyesinde bulunan duygusal eylem; bireyin duygularına bağlı olarak eylemde bulunması durumudur. Yaramazlık yapmasına kızan öğretmenin öğrencisine tokat atması, futbol maçında hakeme kızan futbolcunun hakeme bağırması ya da güzel bir haber alan kişinin sevinçten çığlık atması duygusal eyleme girer. Geleneksel eylem ise bireyin gelenek, adet ve alışkanlıklara bağlı olarak eylemde bulunmasıdır. Küçüklerin, bayramlarda aile büyüklerinin elini öpmesi, kızını istemeye gelenlerden babanın başlık parası istemesi, siftah yapan esnafın parayı yere atması gibi eylemler geleneksel eylem kategorisine girer. Bu eylem türleri mutlaklık içermez, şartlara bağlı olarak farklı tiplere dönüşebilirler. Ancak düşünür, rasyonel olmayan unsurlar üzerinde pek zaman harcamaz, o sosyolojisini daha çok rasyonellik üzerine tesis eder (Weber, 1947:104-107).

\subsubsection{Rasyonellik Çeșitleri}

Pratik-rasyonelliğe geçmeden önce Weberyen sosyolojideki diğer rasyonellik çeşitlerine değinmek önem arz eder. Weber eserlerinde rasyonelliğin çeşitli görünümlerine temas eder. Onun esas ilgi odağında pratik-rasyonellik ve amaçsal-rasyonellik olsa da Weber yeri geldikçe özsel-rasyonellik, formelrasyonellik, değer-rasyonellik, moral-rasyonellik, bilişsel-rasyonellik, metodik-rasyonellik, teknikrasyonellik, biçimsel-rasyonellik ve seçim-rasyonelliği gibi kavramlara vurgu yapar. 0 , rasyonellik görünümlerini farklı isimler altında ele alsa da bazılarından aynı anlamı kastettiğinden, aşağıda sadece formel-rasyonellik, değer-rasyonellik ve amaç rasyonellik izah edilecek, diğer rasyonellik çeşitlerine yeri geldiğinde değinilecektir. 


\subsubsection{Formel-Rasyonellik}

Weber eserlerinde zaman zaman bu rasyonellik türünü biçimsel-rasyonellik olarak da ele alır. Formelrasyonellik ya da biçimsel-rasyonellik bireyin sadece kendi çıkarına odaklandığı rasyonellik türüdür (Jenkins, 2000: 13). Aktörün gerek hedef koyması gerekse hedeflerini gerçekleștirecek yöntemleri belirlemesi tamamen çıkarları doğrultusunda ilerler. Formel-rasyonellikte irrasyonel unsurlar olan duygu ve geleneklerin karar aşamasında herhangi bir etkisi yoktur. Ayrıca öznel değer ve yargllara da müracaat edilmez (Weber, 1947:170; Kalberg, 1980:1155; Tenbruck, 1980:321).

Weber'e göre formel-rasyonellik en güzel kapitalist ekonomik faaliyetlerde somutlaşır. Bu nedenle bireyin kıt kaynaklardan en yüksek faydayı sağlaması ya da minimum maliyetle maksimum kâr elde etmesi formel-rasyonel eylemi oluşturur denebilir. Anlaşılacağı üzere formal-rasyonellik kavramı daha çok örgüt (firma) düzleminde kendini bulan bir ifadedir (Weber, 1950a: 1).

\subsubsection{Değer-Rasyonellik}

Weber değer rasyonelliği, özsel-rasyonellik ve moral-rasyonellikle aynı anlamda kullanır. Ona göre birey, eylem kalıplarını dini ve ahlaki ilke veya değerlere göre şekillendiriyorsa burada değer-rasyonellikten söz edilir (Parsons, 1937:645). Bu aşamada birey kendi faydasından veya çıkarından ziyade dini veya ahlaki bir değere göre hareket eder. Değer-rasyonellik, bireyler tarafından bağlayıcı olduklarına inanılan unsurlar içerir. Bunlar inanç, ödev, sosyal sorumluluk, şeref, haysiyet, onur, sadakat gibi motivasyon kaynaklarıdır (Weber, 1947:106; Duran, 2017:17). Bu yüzden bu rasyonellik türü, doğrudan bir amaç olarak bireyin zihninde yer eder.

Dinin emirleri gereği oruç tutan, namaz kılan, alkol kullanmayan bireyler değer-rasyonel eylemde bulunurlar. Ayrıca askerin ölüm ya da yaralanma riskini göze alıp teröristleri yok etmek için operasyona gitmesi, babanın ailesine daha iyi bir hayat sunabilmesi için ikinci bir işe girmesi de değer-rasyonel eyleme örnektir.

Belirtilmesi gereken bir diğer husus, değerin rasyonel olabilmesi için genel kabul görmesi ve ilkeli bir zemine sahip olması gerekliliğidir. Ancak Weber değer ve yargıları içeren meselelere temkinli yaklaşır. Ona göre ilkelilik üzerine bina edilmiş çeşitli değer sistemlerinden hangisinin daha rasyonel olduğunu tespit etmek zordur.

\subsubsection{Amaçsal-Rasyonellik}

Weber, Batı toplumlarının rasyonelleşmesinin en önemli anahtarlarından biri olarak gördüğü amaçsalrasyonelliği, bireyin yalnızca kendi çıkarını ya da faydasını düşünerek hareket etmesi olarak ifade eder (Weber, 1978:64). Birey her şeyden önce çıkarını olabildiğince arttırmak için ölçülebilir, hesaplanabilir, sistematize edilebilir amaç veya amaçlar belirler. Bu amaç ya da amaçlarını gerçekleștirecek araç, yöntem ve uygulamalardan hangisi daha az maliyetli ya da daha etkin ise ona karar verir (Wilson, 2002:103). Karar sürecinde dini, ahlaki ve geleneksel değerlerin bir geçerliliği yoktur. Birey duygusal davranmak yerine akılcı ve mantıklı hareket eder (Weber, 1947:106; Habermas, 1984:253-254). Yani bu tarz eylemde kişi sadece kendi faydasını, çıkarını, başarısını, gücünü azami seviyeye çıkarmaya çalışır.

İşverenin işçileri asgari ücretten istihdam etmesi, firma sahibinin daha fazla tazminat ödememek için altıncı aya geldiklerinde çalışanlarına çıktı-girdi yaptırması, kişinin yatırım amaçlı faiz hesabına para yatırması, öğrencinin yabancı dil öğrenmek için kursa gitmesi, yüksek nitelikli bir mühendisin çok para kazanmak için yurtdışındaki firmadan gelen teklifi kabul etmesi, yaptırımlardan çekinen yerli firmaların milli otomobil üretmeye yanaşmaması tarzındaki eylemler amaç-rasyonel eylem sinıfına dahildir.

Daha önce zikredildiği üzere Weber Batı toplumlarının rasyonelleşme sürecinde amaçsal-rasyonel çizgide ilerlediğinden bahseder. Hatta o, bu gelişmeyi olumlar, rasyonelleşme sürecini Batı'nın biricikliği olarak niteler ve sadece Batı'nın gerçekleștirdiği bir başarı olarak lanse eder (Weber, 1950a:30). Öte yandan Batı'nın pratik-rasyonel çizgisini de yine Batı'ya özgü bir başarı olarak ele alır (Weber, 1968:238). Ancak Weber bu iki kutup noktası arasında bir denge kurma girişiminde bulunmadığından çelişkili bir durum ortaya çıkar (Harrington, 2000:87). Bu bakımdan kendisinden sonra gelen düşünürler tarafından Weber'in bu paradoksunu çözümlemek adına pek çok teori üretilir.

Buraya kadar Weberyen rasyonelleşme teorisi hakkında kısa ve açıklayıcı bilgiler verildi. Aşağıda ilk olarak pratik-rasyonellik bağlamında kavramsal çerçeve çizilecek, ardından bu olgu tarihsel süreçte Weberyen paradigma çerçevesinde inşa edilmeye çalışılacaktır. 


\subsection{Pratik-Rasyonellik}

\subsubsection{Pratik-Rasyonellik Kavramı}

Weber'e göre pratik-rasyonellik amaç, araç ve değer-rasyonelliklerinin sistematik şekilde bütünleşmesidir. Bu açıdan Weber amaç-rasyonellik ile değer-rasyonellik şartlarının bir eylem veya kararda mevcut bulunmasını pratik-rasyonellik olarak ifade eder (Weber, 1946b: 284; Weber, 1950a: 55, 71, 77; Habermas, 1984:250). Anlaşılacağı üzere düşünür, övgüyle bahsettiği pratik-rasyonellikten; amaçların ve amaçlara ulaştıracak araçların tayin edilmesi ve sürecin her aşamasında akılcı ve ahlaklı olunması olarak bahseder.

Daha geniş bir izahla pratik-rasyonellik, bireyin ihtiyacını karşılamak üzere rasyonel amaç ya da amaçlar ortaya koyması; sonrasında bu amaç veya amaçları karşılayan en uygun, akılcı, verimli, etkin ve az maliyetli araç, yöntem ve uygulamaları araştırması ve kıyaslaması; beklentilerin gerçekleşip gerçekleşmeme ihtimallerine hazırlıklı olması ve ortaya çıkabilecek beklenmedik şartlara karşı stratejiler üretmesi; tüm bu eylem ve karar sürecinde kendi çıkarını, başarısını, faydasını da gözeterek dini ve ahlaki değerlere göre hareket etmesidir.

Yukarıda bahsedildiği üzere bir eylemin amaçsal-rasyonelliği rasyonel amaç-araç ilişkisinde temellenir. Amaç-rasyonel tarzındaki bir eylemin bünyesinde etkin konumda olan araçsal-rasyonellik; belirli ve rasyonel amaçlarda araç istihdam etmenin etkili bir biçimde planlanmasıyla şekillenir (Weber, 1978: 6364). Aynı eylemin seçme-rasyonelliği ise açık şekilde benimsenen değerlerde, verili yöntem ve uygulamalarda ve sınır şartlarında amaçların hesaplanabilirlik ölçütüne göre oluşur (Weber, 1947: 114115; Weber, 1950b:302-315). Diğer yandan bu eylemin normatif-rasyonelliği; bireyin ön planda tuttuğu dini ilke ve değerlerin zihni ve akli angajmanlarınla uygun olup olmamasına, aynı zamanda da düzen kurucu, sistematiklik sağlayıcı ve nüfuz edici gücüne göre teşekkül eder (Weber, 1947:170-171; Duran, 2017: 18).

Bu meyanda Weber, araçsal-rasyonellik ve seçim-rasyonelliğinin şartlarını birlikte ikame eden eylemleri amaç-rasyonel ya da biçimsel-rasyonel, normatif-rasyonellik şartlarını temin eden eylemleri moralrasyonel, amaçsal-rasyonel ve moral-rasyonel şartlarının aynı eylem çatısı altında içselleştirilmesini de pratik-rasyonel eylem olarak gündeme getirir (Weber, 1978: 424; Chowers, 1995: 129). Yani bu eylem tipi, araçsal-rasyonelliği ifade eden teknik ihtiyaçların karşılanması ve etkili araçların hazır ve işler konuma getirilmesi; seçme-rasyonelliğini ifade eden eylem alternatifleri arasından doğru ve tutarlı bir tercihte bulunulması; normatif-rasyonelliği ifade eden dini ve ahlaki ödevlerin, ilkelilik üzerine kurulu bir etik kapsamında yol göstericiliğinin benimsenmesi özelliklerini içeren üç rasyonel eylem kalıbının senkronize şekilde ve bağlantılı olarak 'kuvveden fiile geçmesi' olarak ifade edilebilir. Ayrıca bu özelliklerinden dolayı pratik-rasyonel eylem, insan fitratına en uygun eylem türüdür denebilir.

\subsubsection{Pratik-Rasyonelliğin Dinamikleri}

Pratik-rasyonellik kavramından anlaşıldığına göre bu olgu bir takım temel esaslar üzerine kuruludur. Bunlar genel olarak üç dinamik altında ileri sürülebilir.

\subsubsection{Rasyonellik}

Rasyonellik, mikro açıdan ele alındığında bireyin rasyonel davranması esasına dayanır. Günlük pratiklerinde, başka bireylerle olan ilişkilerinde, iş ve aile hayatında, ileriye dönük kısa ve uzun vadeli planlarında vb. durumlarda bireyin akıl mekanizmasının daima açı olduğu söylenebilir. Bu nedenle kişinin zihinsel aktiviteleri, eylem güdü ve içerikleri, kıyaslama ve hedefe odaklanma yeteneği ileri seviyededir. Buna göre rasyonellik öznenin tüm yaşam alanını dizayn eden bir olgudur denebilir.

Makro boyuttan değerlendirildiğinde ise devlet aygıtının ve kurumlarının, özel sektördeki firmaların, bunların birbirleriyle olan ilişkilerinin rasyonel temellere göre inşa edilmesinden söz edilebilir (Weber, 1978: 71-72).

\subsubsection{Menfaat: Fayda ve Kâr}

Bireyin (tüketici-üretici) eylemde bulunmasının amacı faydasını veya kârını azamileștirme isteğidir. Kişi herhangi bir karar alırken çeşitli seçenekler arasından kendisine en çok yararı sağlayacak ya da en çok gelir getirecek olanı tercih eder. Veri amaca ulaşabilmenin önemli yollarından biri en az zahmete katlanma ile gerçekleşir (Weber, 1978: 68-69). Bu ise firma bazında maliyetlerin minimize edilmesi durumudur. Elbette siyasette, ekonomide, hukukta vb. bütün sistemlerde aynı anlayış geçerlidir (Yee, 1997: 1048). 


\subsubsection{Illkelilik}

İlkelilik, mikro ve makro birimlerin eylemlerinin belirli ilke ve değerlere göre şekillenmesidir. Yani birey faaliyetlerinde maksimum fayda elde edeceği akılcı hedefler belirler, hedefine ulaşmak için etkin yöntemleri seçer, bu süreçte dini ve ahlaki ilkelere göre davranır. Sadece kendi menfaatini değil, karşısındakinin ya da içinde yaşadığı toplumun genel menfaatini de dikkate alır (Weber, 1950a: 75).

Kısaca pratik-rasyonellik dinamiklerinin özünde insanın günlük hayatını kolaylaștırma, hayatı ve çevreyi daha yaşanabilir kılma, fayda ve kârı optimum ahlak noktasına çıkarma, toplumsal rızayı ve konsensüsü tesis etme, özgür ve mutlu bireyler yetiștirme, sosyal refahı arttırma, adilane ve barış̧̧l bir toplum inşa etme gibi idealler yatar.

\subsubsection{Pratik-Rasyonelliğin Toplumsal Sistemin Alt Şubelerine Nüfuz Etmesi}

Görüldüğü gibi pratik-rasyonellik ideal birey ve toplumun oluşması açısından büyük önem arz eder. 'Olması gereken'i ya da neyin ve nasıl yapılması gerektiğini temsil eden bu modelin genelleștirilmesi ve toplumsal değer alanlarına entegresi ideal düzeni veya üstün iyiyi gerçekleștirmek anlamına gelir. Yani pratik-rasyonelliğin ekonomi, hukuk, siyaset, sanat, bilim ve yargı gibi alanlara egemen olması, bu yapıların dini ve ahlaki değerlere göre dizayn edilmesini sağlar. Örnek olarak ekonomi ve siyaset alanlarının pratik-rasyonellik anlayışıyla örgütlenmesi Weberyen düşünceye göre kısaca izah edilecektir.

\subsubsection{Ekonomi Alanında Pratik-Rasyonellik}

Ekonomiye pratik-rasyonelliğin nüfuz etmesi bu alandaki politikaların, faaliyetlerin, kurumların, tedbirlerin, yasakların vb. hususların hem kârı azamileştirici ve başarı sağlayıcı nitelikte ortaya konulmasını hem de dini, ahlaki ve insani değerlerin ön plana alınmasını gerekli kılar. Bu șekilde kolektif aktörlerin kâr maksimizasyonuna odaklanmış mekanik organizasyonlar kılıfindan sıyrılıp insanı, firma ailesini, çevreyi, tabiatı ve gelecek nesillerin tüketim kaynaklarını önemseyen faaliyetlerde bulunmaları sağlanır (Weber, 1950a: 75).

Ekonomik eylemde bulunan birey ise tabiatı gereği yine fayda maksimizasyonu amacıyla hareket eder. Pratik-rasyonel eylemde bulunan birey bu alanda kendi kârını, çıkarını, başarısını sağlamaya çalışırken aynı zamanda iletişim halinde olduğu bireylerin haklarını gözeten, kamu yararına aykırı davranmayan, yaşadığı çevreyi kendi evi gibi koruyan ve benimseyen, doğabilecek zararları yok etmeye çalışan ve gelecek kuşakların kaynaklarını sömürmek bir yana daha da arttırmaya çalışan bir anlayışla faaliyette bulunur (Weber, 1950a: 76; Laiz and Schlichte, 2016:174).

Esasında tüm bunlar günümüz ekonomi dünyasında ulaşılmaya çalışılan en önemli makroekonomik hedeflerden biri olan 'sürdürülebilir kalkınma'nın daha geniş kapsamlı ve ideal bir boyutunu oluşturur. Elbette bu meşru düzende olumsuzluklara yer yoktur (Weber, 1950a: 44-46). Sömürgecilik, yolsuzluk, gasp, haksızlık, zulüm gibi toplumsal ve insani değerleri zedeleyen en ufak menfilik dahi dini ve ahlaki ilkelerin egemen kıldığı etik tarafından en başta bertaraf edilir. Çünkü pratik-rasyonel ekonomi etiğinin aksiyomunun tamahkâr, bencil, çıkarcı, maddeperest ve hazcı bir yapıda olması beklenemez. Tersine pratik-rasyonel ekonomi etiği adil, paylaşımcl, dayanışmacı, merhametli, şefkatli ve hakkaniyetli davranışları önerir ve özendirir.

\subsubsection{Siyaset Alanında Pratik-Rasyonellik}

Weber, Politics as a Vocation adlı makalesinde bir yöneticinin pratik-rasyonel özelliklerini ortaya çıkarmaya çalışır (Weber, 1946a:77-128). Ona siyaseti meslek olarak seçmiş bir politikacının nihai amacı iktidar olmaktır. Politikacılar farklı nedenlerden dolayı iktidarı amaçlar. Buradaki sebep, politik eylemi ideal eylem tiplemelerinden herhangi rasyonel ya da irrasyonel kategoriye koyabilir. Weber için önemli olan siyasete yön verecek politikacının ya da siyasi liderin hangi özelliklere sahip olması gerektiğidir.

Esasında Weber bu meseleye etik açısından yaklaşır. 0, etik ve siyaset arasında sıkı bir bağ kurarak, ideal bir politikacı profilinin etik kodlamasını yapar. Weber bu meseleye ilişkin iki ayrı pencere açar. Bunlardan biri inanç etiği, diğeri sorumluluk etiğidir (Ritzer, 1975:631).

İnanç etiğinde politikacıyı harekete geçiren motivasyon kaynağının ne olduğu ön plandadır. Bu yüzden inanç etiğine sahip politikacı, eylemin sonucundan ziyade çıkış noktasına odaklanır. İnanç etiği dini ya da geleneksel değer ve yargılara göre şekillenir. Buna bağlı eylemlerin belirli bir kalıp dışına çıkması zordur. Bu bakımdan rasyonel olan inanç etiğinin değer-rasyonel eylemi karşılayabileceği söylenebilir.

Sorumluluk etiğinde ise, politikacı kendi eyleminin ortaya çıkan sonuç ya da sonuçlarından sorumludur. İyi politikacı benimsediği politikaların sonuçlarını takip etmelidir. 0 , bu süreçte bütün şartları hesaba katar ve somut veriler üzerinden hareket eder. 
Weber bu konuda aslan payını sorumluluk etiğine verir. Çünkü ona göre sorumluluk etiği, siyasal etiğin özdeşidir. Politikacılar eylemde bulunurken ya da karar mekanizmalarını çalıştırırken öngörülebilir sonuçlara odaklanmalıdırlar. Gerek karar aşamasında tahmin edilen sonuçların gerçekleșmesi gerekse beklenmedik sonuçların ortaya çıkması durumunda kendini sorgulaması gereken kişi politikacıdır. Ona göre iyi politikacı ya da siyasi lider sorumluluk sahibi olup halka verdiği sözleri tutmalı ve sonuçlarına katlanmalıdır. Sorumluluğunu yerine getiren politikacı siyasal açından etik davranıyor demektir. Yani Weber'in kurgusunda politikacılar, özellikle sorumluluk etiğine sahip olmalıdır. Toplumsal eylemin sonuçlarına yoğunlaşan sorumluluk etiğinin ise öznel değer ve yargıları dışlayan amaç-rasyonel eylemi karşıladığı öne sürülebilir.

Weber'in anlayışında meslek olarak siyasetle uğraşan iyi bir politikacı bu süreçten iki boyutlu kazınım elde eder. Politikacı mesleki faaliyeti gereği belirli bir gelir sağlar ve bir güç alanında yer almasından dolayı manevi doyuma ulaşır. Ancak kişi tamamen ekonomik çıkar sağlamak adına siyasete atılmamalıdır. Ayrıca siyaset mekanizmasının büyüsüne kapılıp güç sarhoşluğuna yenik düşmemelidir. Bu açıdan nesnellikten kopmamalı, sorumsuz ve kibirli davranışlardan kaçınmalıdır. Yetkisini kötüye kullanmamalıdır. Demagoji yapmamalıdır. Toplumsal değerleri önemsemelidir. Esas amacından sapmamall, seçmen kitleye hizmet yolunda ilerlemelidir. Kendini vatandaştan üstün görmemelidir. Sadece itibarını düşünmemelidir. Aldığı kararların arkasında durmalı ve süreci takip etmelidir. Sorumluluğunun bilincinde olarak șeffaf bir siyaset izlemelidir. Disiplinli, dikkatli, özenli ve özellikle basiretli olmalıdır.

Weber eserlerinde pratik-rasyonellik dinamiklerinin siyaset alanındaki izdüşümünü verir. Ona göre başarılı politikacı ideal tipi şu üç esas ilke üzerinde șekillenir: Hırs, sorumluluk duygusu ve denge. Hırs, mesleğine tutkuyla bağlanmayl; sorumluluk duygusu, bu mesleğin sorumluluğunun gereklerini ve şartlarını yerine getirmeyi; denge, ortaya çıkan durumları olgun bir şekilde karşılamayı, olaylara ve kişilere karşı dengeli, ölçülü ve mesafeli yaklaşım sergilemeyi ifade eder. Bu ilkelerin siyasi lider tarafından içselleștirilmesi pratik-rasyonelliğin siyaset alanına nüfuzuna ortam hazırlar.

Bilindiği üzere siyaset mücadele alanıdır yani bir nevi gerilim alanıdır. Olumsuzlukların teşekkülü bu alan için tabii bir özelliktir. Bu tarz durumlarda iyi politikacı korkusuz olmalıdır. Olaylar ve faaliyetler üzerinde derin bilgi edinmelidir. Yapması gerekeni yapmaktan çekinmemelidir. Başarısız bile olsa bunu kabullenebilmeli, hatalarını öğrenmeli ve bunları düzeltmelidir. Çünkü sorumluluk etiğine sahip politikacı hesaplanabilir ve ölçülebilir eylemler sergiler. Burada, 'olan' şey, politikacının başarı derecesini ölçmeye yarar.

Neticede siyasete yön veren politikacı rasyonel amaçlar belirlemeli, amaçları gerçekleştirecek rasyonel araçlar seçmeli ve bunları yaparken değerleri de ön plana almalıdır. Etikten yoksun bir siyasi eylemin irrasyonel özellikler barındırması muhtemeldir. Çünkü siyasetin güç alanı oluşu bu eğilime müsait bir zemin hazırlar. Bu bakımdan Weber'e göre inanç etiği ve sorumluluk etiği birbirinden ayrı özellikler içerse de birbirleriyle akıl alışverişi yapabilirler. Bu nedenle başta iki ayrı etik türü gibi görülen inanç ve sorumluluk etiği birbirlerinin tamamlayıcısı niteliğinde görülmelidir.

Yukarıda belirtildiği gibi Weber eserinde politikacının önce sorumluluk etiğine sahip olması gerektiğini söyler, sonrasında ise bu görüşünü daha da genişletir. Weber'in düşüncesinde iyi bir politikacl, pratikrasyonellik şartlarını sağlayan inanç ve sorumluluk etiği arasında optimum denge kurabilirse amacına başarılı bir şekilde ulaşabilir.

Dolayısıyla ekonomi ve siyaset alanı gibi diğer sistemlerin de pratik-rasyonel şekilde inşa edildiği bir toplumda insan özgür ve akıl sahibi bir fert olarak hem kendini ve çevresini hem de içinde yaşadığı toplumu maddi ve manevi olarak geliştirici özelliklere sahip olur.

\subsubsection{Pratik-Rasyonel Eylem Tarzına İlişkin Örnekler}

Pratik-rasyonellik kavramı en çok insan eylemlerinde somutlaşır. Bu yüzden güncel ve gündelik hayata dair çeşitli örneklerden bahsetmek faydalı olacaktır.

Bireyin sadece para kazanmak için gece gündüz aralıksız mesleğini icra etmesi amaç-rasyonel eylem, onurlu bir hayat sürmek için çalışması değer-rasyonel eylem, Allah emrettiği için (Furkan/47) yetenek ve kabiliyeti ölçüsünde meslek edinip çalışması, gelir sağlaması ve kendini sürekli geliştirme amacında olması pratik-rasyonel bir eylemdir.

Bir girișimcinin riskleri göze alıp kâr elde etme amacıyla bir ișletme açması amaç-rasyonel eylem, arkadaşının 'sen bu işi başaramazsın' deyişine kızıp işletme açması duygusal-eylem, sokak hayvanlarının barınmasını sağlama amacıyla tesis açması değer-rasyonel eylem, hem gelir elde edip ailesini geçindirmek hem de topluma faydalı olmak amacıyla özel kütüphane açması pratik-rasyonel eylemdir. 
Bir kişinin para kazanmak için sermayesini yüksek faizden bankaya yatırması amaç-rasyonel eylem, faizin dinen yasak olduğunu ve zengin-fakir arasındaki uçurumu genişlettiğini gözeterek kâr elde etme amacıyla sermayesini altına yatırması pratik-rasyonel eylemdir. Ya da faiz sistemi üzerine kurulu bankacilık faaliyetleri amaç-rasyonel; faizin dinen haram olmasından dolayı faizsiz yöntemler geliştirip firma ve şahıslara finansman sağlayan bir kurumun faaliyetleri pratik-rasyonel eylemlerdir.

Bir firmanın gelişme amacıyla endüstri 4.0'ı transfer etmesi ve robotik üretime geçmesi amaç-rasyonel eylem, bunu yaparken iş̧̧ileri doğrudan işten çıarmak yerine onlara iş bulana kadar istihdam imkanı sağlaması ve işsiz kalmalarını önlemesi pratik-rasyonel eylemdir.

1970'lerde üretilen Ford Pinto marka arabanın kaza anında ciddi bir problemi ortaya çıkar. Arkadan çarpmalı kazalarda arabanın benzin deposu çoğu zaman patlar, araba içindeki kişiler ya ölür ya da ağır yaralı olarak kurtulurlar. Kazazedelerden biri Ford Motor Şirketi'ne dava açar. Bu duruma neden olan parçanın bilinçli bir şekilde takılmadığı ortaya çıkar. Ford'un yaptı̆̆ı fayda-maliyet analizine göre benzin deposuna takılması gereken küçük parça 11 dolardır. Üretilen 12.5 milyon araca bu parçayı taktırmak yüksek maliyetlidir. Oysa kazalar sonucu yıllık ortalama 180 ölüm ve 180 yaralanma gerçekleşir. Ford şirketi kazada ölen her kişi için 200 bin dolar, yaralanma için 67 bin dolar tazminat ödemeyi kabul eder. Bu durumda parça takılırsa șirkete maliyeti 137,5 milyon dolar, takılmazsa ödenecek tazminat yaklașık 49 milyon dolardır (Dowie, 1977:18-32). Ford'un tercihi, fayda-maliyet analizi sonucu benzin deposuna bu parçayı taktırmamaktan yana olur. Firmanın bu davranışı amaç-rasyonel bir eylemdir. Fakat firma maliyetlerin artmasına rağmen olabilecek kazalar için araç içindeki bireylerin güvenliğini sağlayıcı her türlü tedbiri üretim sürecine dahil edip önlemler alsaydı pratik-rasyonel eylemde bulunmuş olacaktı.

İşverenin daha fazla tazminat ödememek için 6. aya gelindiğinde çalışanlarına çıktı-girdi yaptırması amaçrasyonel eylem, bu şekilde bir politika izlemeyip çalışanlarının aidiyetliğini kazanmayı ve motivasyonlarını arttırmayı istemesi ve onlara hak ettiği gibi davranması pratik-rasyonel eylemdir.

Türkiye (Tüpraş) ve Rusya'nın maksimum verim amacıyla çevresel olumsuz etkilerini azaltıcı tüm tedbirleri almadan rafinerilerde petrol işlemeleri amaç-rasyonel eylem, Norveç'in petrol rezervleri bulunmasına rağmen temiz çevre, su, iklim gibi unsurları öne alarak çıkarılan petrolü işlenmek üzere Rusya gibi başka bir ülkeye taşıması pratik-rasyonel eylemdir.

Bir kişinin ailesinden gördüğü üzere herhangi bir siyasi partiye oy vermesi geleneksel-eylem, kendi hayat görüşüne uymayan ancak sadece iş garantisi veren bir partiye oy vermesi amaç-rasyonel eylem, yöneticilerinin hem toplumun refahını arttırmaya hizmet edecek hem de dini ve ahlaki ilkelere göre karar alacaklarını bildiği partiye oy vermesi pratik-rasyonel eylemdir.

Vajrayna Budizmi'ne göre öldükten sonra yeniden doğuma inanılır. Özellikle Çin'in Tibet Bölgesi'nde yaygın olan Budist inanıșında cesetler rahipler tarafından parçalanarak akbabalara yedirilir ve bu şekilde ruhun başka bedenlerde doğacağı inancı hakimdir. Bu eylem geleneksel eylem tipine örnektir ve irrasyoneldir. Bir kişinin, hayattayken hiç sevmediği birinin cesedini kızgınlıkla yakması duygusal eylemdir ve yine irrasyoneldir. İnsan cesedi, et yiyen böceklerin oluşturduğu bakterilerin hareketleri sonucu dört yüz farklı bileşimden yayılan koku nedeniyle çok geçmeden çürük et gibi kokmaya başlar. Rahatsız edici bu koku nedeniyle cesedin gömülmesi ise amaç-rasyonel eylemi oluşturur. Müslüman bireyin inancı gereği cesedi gömmesi (Maide/31) bunun yanında bilimsel açıdan bu işlemin yapılması gereğine vakıf olması pratik-rasyonel eylemdir.

Anlaşılacağı üzere pratik-rasyonel eylem tarzının genelleşmesi ve kurumsallaşması rasyonel bir hayat tarzına zemin hazırlar. Weber'e göre bu gelişme tarihsel süreçte 'Protestan Etik'e bağlı hayat tarzına tekabül eder. Son olarak pratik-rasyonelliğin fiiliyatta somutlaștığı bu tarihi olgudan hareketle aşağıda Weber'in pratik-rasyonelliği nasıl inşa ettiği araştırılacaktır.

\subsection{Weber'de Pratik-Rasyonelliğin Somutlaşması: Protestan Etik}

Weberyen paradigmada, Batı toplumlarının modern kapitalizme geçiş süreci ve bu tarihi gelişme rasyonelleşme olgusuyla açıklanır (Habermas, 1989:81; Roth, 1976:316). Weber çağdaşlarından farklı olarak dini ve ahlaki ilkelerin rasyonelleşme sürecinde etkin rol oynayabileceğini ileri sürer. 0 , bu noktada modern kapitalizm ve rasyonelleșme sürecini özdeșleștirip, bu tarihsel olgunun ortaya çıkmasında çok büyük paya sahip olan Protestan etiğe odaklanır (Weber, 1950a: 35; Weber, 1968:226 vd.). Weber'e göre Protestanlı̆̆ın ve özellikle de Kalvinizm kolunun bașlıca değerleri, diğer dinlere mensup kitlelerin sahip olamadığı imkanları inananlarına sunar. Püriten ilkeler modern kapitalizmi gün yüzüne çıkaran motivasyonu üreten ve tedarik eden en önemli referanstır (Weber, 1950a:44). Bu nedenle Weber pratikrasyonelliğin inşasında Protestan etiğin temel dinamiklerinden yararlanır. Bunlar kadercilik; seçilmiş kullar, meslek; ibadet, asketizm; aktif-riyazetçi azizler ve rasyonel hayat tarzına tekabül eden metodik- 
rasyonellik olarak temellendirilebilir (Weber, 2013:3; Weber, 1950a:76). Yani o, pratik-rasyonellik anlayışının Protestan etikle pratiğe döküldüğünü belirtir.

Kısaca izah etmek gerekirse Weber'e göre Protestanlığın kalburüstü akımlarından olan Kalvinizm'de inananlar daha doğmadan kaderlerine teslim olurlar. Kalvinizm'in kadercilik anlayışına göre insanlar iki gruba ayrılır. Bunlar kurtuluşa erenler ve ebedi cehennemliklerdir. Ne var ki inanan birey için dünyevi hayatın en önemli gayesi Tanrı diyarında ebedi ikamet hakkı elde etmek iken, Tanrı insanoğlunu kendi gerçeğinin bilgisinden mahrum kılar. Bu belirsizlik ve bilinmezlik vahametinden kurtulmanın tek yolu seçilmişliğin işaretlerine sarılmaktır. Calvin ileri sürdüğü yorumlarla Püritenlerin bu endişelerine son verir. Ona göre Tanrı insanlara dünya hayatını sürdürmeleri için çeşitli meslekler lütfeder. Birey, farklı meslek dalları arasından özelliklerine en uygun olanı seçmeli ve o meslekte kendini geliştirip derinlemesine bilgi sahibi olmalıdır. Mesleki faaliyet sürecinde ortaya çıkan zenginlik veya başarılar Tanrı'nın huzurunda seçilmişliğin bir alametidir. Kalvinist akımda Tanrı'ya yapılacak ibadet, sadece çalışma ya da mesleki faaliyete indirgenir denebilir. Çünkü irrasyonel olarak inanan bireyin kendisini mesleğine adaması modern kapitalizmin ihtiyaç duyduğu önemli bir adımdır. Başka bir söylemle manastırlara hapsedilmiş irrasyonel eylem yerine dünyaya egemen olmaya yönelik rasyonel eylem ikame edilir. Dünyaya yönelik asketik bakış açısı doğrultusunda, düzensiz ve gündelik işler rasyonel, sistematik ve metodik mesleki eyleme dönüşür. Elde edilen gelir ve servetin israf edilmesi ve gereksiz yerlere harcanması yasaklanır. Bunun yerine tüm birikimin dini ve ahlaki ilkelerin motivesiyle yeniden rasyonel yatırıma aktarılması yaygınlaşır. Lüks ve gösteriş tüketiminden uzak durulur, inanan için sade bir hayat önerilir. Bu sayede ekonomik kazanç ve başarılar zenginliği de beraberinde getirir. İş hayatında doğruluk, çalışkanlık, dürüstlük ve güvenilirlik gibi değerler ön plana çlkarılır (Weber, 1950a: 69-71; Weber, 1965: 252-261). Yani Püritenin mesleki faaliyeti sonucu kazanç sağlaması, bunu israf etmeyip tasarrufa yönelmesi, sonrasında servetini gelir getirici yatırıma dönüștürmesi ve bunu hayatında sürekli kılması adeta cennete ulaşmanın şifresi olarak ele alınır.

Görüldüğü gibi Weber, Protestan ilkelerine bağlı metodik-rasyonel hayat tarzını hem amaç-rasyonel hem de moral-rasyonel özellikleri içeren pratik-rasyonelliğin somutlaşması olarak belirtir (Weber, 1950a: 4750; Reckling, 2001:170).

Diğer yandan Weber'in sosyolojisinden ortaya çıkarılan pratik-rasyonellik kavramını Kant'ın felsefi bir yaklaşımla ele aldığı görülür (Rutgers and Schreurs, 2006:403-421; Barker, 1980:226). Kant'ın bahsi geçen konuya ilişskin felsefi düşünceleri çalışmanın amacının daha net anlaşılmasını sağlayacaktır.

\section{KANT'DA PRATIK-RASYONELLIKK}

Batı düşünce dünyasının önemli isimlerinden olan Immanuel Kant'ın pratik-rasyonellik tasarımı özellikle Aristo'nun anlayışına benzer özellikler içerir (Aristotle, 1906: 140; MacInthyre, 1988: 103 vd.). Alman filozof The Metaphysic of Ethics isimli eserinde pratik-rasyonelliğin başlangıç noktasına kadar ulaşmaya çalışır. Onun bu girişimi pratik-rasyonel eyleme bir kaynak belirleme çabasıdır denebilir.

\subsection{En Üstün Amaç: İyiyi İstemek}

Kant'ın düşüncesinde birey için en önemli şey iyiyi istemektir ki iyi olan da budur. Ancak iyiye yönelme başlı başına yeterli değildir. Düşünür bu konuya ilişsin nüansları vurgulayarak açılamasına devam eder. Anlama kabiliyeti ve zekilik gibi doğal yetenekler, kararlılık ve korkusuzluk gibi karakter özellikleri ya da güçlülük ve zenginlik gibi talihli olma durumları hem iyidir hem de istenilen değerlerdir. Bu değerlerin iyi olması pratik-rasyonellik sürecinin sadece bir parçasıdır. Diğer yandan bu değerler bireyin kötü amaçlılığına da hizmet edebilir. Soğukkanlı veya kendine hakim olmak iyi bir özellikken kötü niyetli birinin bu ve benzer özelliklere sahip olması onu tehlikeli birine dönüştürebilir. Pratik-rasyonellik için asıl mesele ise eylemleri motive ve inşa edici değerlerin ne amaçla benimsendiğidir (Kant, 1886: 3-4; Philips, 1987:195).

Bu bakımdan Kant'ın söylemiyle tüm her şey iyi için yapılmalıdır ve iyi olduğu için istenmelidir. Yani hiçbir alt amaç olmaksızın en önemli amaç iyi olanı istemektir (Kant, 1886: 8). Eylemin sonucu, etkisi, yöntemi ne olursa olsun iyiliğin ya da eylemlerin değerinin esas belirleyicisi bir şeyi iyi olduğu için tercih etmektir. Benimsenen iyi değerin faydalı ya da etkisiz olması ön planda değildir. Hatta bu, mutlak iyiliğe hiçbir değer katmaz çünkü istenilen şeyin özü zaten iyidir (Kant, 1886: 4). İyi, iyi olduğu için yapılmalı anlayışının bir parçası da doğru bir amacın doğru neden veya nedenlerle yapılması gerektiğidir. Bu da düşünürü ödevler dürtüsüne götürür.

\section{2. Ödev Dürtüsü ya da Sorumluluk Bilinci}

Kant'a göre bireyin görev, ödev veya sorumluluk bilincinde olması onun en kıymetli amacına uygun davranmasını sağlar. Kant bireyin ödeve uygun davranması ile ödevden kaynaklı eylemde bulunması 
arasında bir çizgi çeker. Dahası o, bir şekilde faydalı olsa dahi ödeve aykırı eylemler, ödevle çatışan eylemler, ödeve uygun olsa da tercih edilmeyen ya da dolaylı bir eğilim sergileyen eylemler, ödeve uygun olup eğilim duyulan ama ne amaçla yönelim gösterildiğinin ayırt edilmesinin çok zor olduğu eylemleri bir kenara bırakır. Kant'ın düşüncesinde pratik-rasyonel eylem ödev kaynaklı ve ahlaksal değere sahip bir eylem türüdür. Zaten onun pratik-rasyonellik olgusu, ahlakın üstün ilkesini ortaya koyma girişimidir (Kant, 1886: 8-10).

Bu bağlamda Alman düşünür faydacı yaklaşımın karşısında bir tavır sergiler. 0, ahlaksal eylemi çıkar, fayda, haz, mutluluk gibi amaçlardan soyutlayarak yalnızca ödev bilinci ya da güdüsüyle yapılan bir kategoride ele alır (Harsanyi, 1977:632).

\subsection{1. Ödevler Dürtüsü-İstekler Dürtüsü Ayrımı}

Kant ödevler dürtüsünü bireyin eylem sürecindeki ahlakiliğinden ortaya çıkarır. Ona göre eylemin sonuçları değerlendirmeye alınmamalıdır. Eylemin ahlaksal değerine bağlı olan ödevler dürtüsü kapsamında bireyin sahip olduğu özel ödevler yoktur. Eylemler çıkar amaçlı gerçekleştiriliyorsa ahlaki bir değerden söz edilemez. Kant bu tarz eylemlerin kaynağı olarak istek dürtüsünü gösterir. İstek dürtüleri ile ödev dürtüleri Alman düşünürün tasarımında karşı kutupta yer alır (McLear, 2015:89).

Kant incelemesini örneklerle daha anlașlır hale getirmeye çalıșır. 0, istek ve ödev arasındaki ayrımı vurgulamak için bakkal ve çocuk arasındaki satış örneğini verir. Bu örneğe göre küçük çocuk alışveriş yapmak için bakkala gider. Bakkal küçük çocuğun akıl baliğ olmamasından ya da deneyimsiz olmasından yararlanmak isteyebilir. Çocuğun almak istediği ürünün fiyatını yüksek söyleyebilir ve çocuğu kandırıp ona yüksek fiyattan mal satabilir. Ancak örnekte bakkal çocuğa istediği ürünü normal fiyatından verir. Burada bakkal doğru olanı yapar. Kant'ın odaklandığı mesele ise bakkalın bu davranışı hangi amaçla yaptığıdır. Bakkal çocuğa yüksek fiyattan ürün satmasının başkaları tarafından duyulduğunda satışlarının azalacağını düşündüğü için çocuğa ürünü normal fiyatından satar. Bu nedenle bakkal doğru olanı yanlış amaçla yapar. Kant'a göre bakkalın davranışı doğru olsa da ahlaki değeri yoktur.

Bakkalın küçük çocuğu aldatmaması ödeve uygundur. Ödeve uygun olması dürüstlük ilkesine göre hareket ettiğini göstermez. Ticaret yaparken dürüstlüğü kendisi iyi olduğu için değil de mevcut müşteri kitlesini kaybetmemek için benimsediğinden bakkalın ödev dürtüsü ile değil, istek dürtüsüne göre hareket ettiği ortaya çıkar. Oysa ticarette dürüstlük herhangi bir çıkar beklemeden sadece iyi olduğu için tercih edilmelidir. Örnekten anlaşılacağı gibi Kant'ın ödev dürtüsü eyleme ahlaksal değerini sağlar (Kant, 1886: 8).

\subsection{2. Ödev Kaynaklı İyilik}

Kant'a göre iyilik yapmak veya yapılabildiği yerde iyilik yapmak ödevdir. Daha da önemlisi ise şartların elverişsizliğine rağmen iyilik yapabilmektir. Bireyin mutlu bir anında, imkanı varken, kendini motive eden güce sahipken bașka bireylerin problemlerini çözmeye çalışması ahlaksal içerikten yoksun ödevden dolayı eylemlerdir. Ancak birey türlü problemlerle boğuşurken, hiçbir çıkarı yokken, onu motive edici kanallar sorunlarla kapanmışken başka bireylerin problemlerini çözmeye çalışırsa eylemin ahlaklılığından ve ödev kaynaklı olmasından söz edilebilir (Kant, 1886:9). Kant bu meyanda kötü komșunun bile sevilmesini öneren düşünceyi pratik-rasyonelliğin göstergesi olarak vurgular. Çünkü bu tarz eylemde bulunan kişi tamamen iyilik odaklı ve ilkeli hareket eder (Kant, 1886:11, 19).

Bir diğer ifadeyle Kant, bir eylemin pratik-rasyonel kabul edilebilmesi için ilkeli bir amaçlılık şartını sunar. Pratik-rasyonelliğin temel taşlarından biri olan ahlaksal değer, eylemin amacında değil de ona yönlendiren iç ilkelerde saklıdır ve bu da ödev kaynaklıdır.

Ahlaki değer açısından bir eylemin ilkeliliği aynı zamanda yasalara uygunluğuna işaret eder (Kant, 1886: 13). Birey eylemde bulunmanın ya da bir şeyi istemenin ilkesini aynı zamanda genel bir yasa olarak görmekten rahatsızlık duyacaksa bu ilkeye göre hareket etmeyi tercih etmemelidir. Eylemin ilkesini gönül rahatlığı içinde bir yasa olarak da kabul edebiliyorsa doğru adımı atabilir. Bu da zaten pratik-rasyonellik için gerekli üstün iyi demektir (Kant, 1886:15).

Kant'ın pratik-rasyonellik kurgusuna bakıldığında insanı esas alan bir anlayışa sahip olduğu anlaşılır.

\section{3. İnsan Bir Öznedir}

Kant'ın düşüncesinde insan bir 'șey' değildir, bu yüzden araç olarak kullanılamaz, araçsallaştırılamaz (Kant, 1886: 43). Ona göre insan bir öznedir, bir amaçtır. Bu yüzden insan saygıdeğer bir varlıktır. Akıl sahibi, rasyonel, özerk ve özgürdür. Bu özellikler eylem sürecinde herkes tarafından olması gerektiği gibi kullanılmaz. Buna karşın o tüm ahlaki ilkelerin insan amaçlı kurgulanması gerektiğini ileri sürer (Kant, 1886: 24). Bütün eylemlerin amacı insan olmalıdır. Birey başka birine yönelik eylemde bulunurken nasıl 
ki kendini amaç olarak görüyorsa karşısındakini de amaç olarak görmeli, ona göre eylemde bulunmalıdır (Kant, 1886:42; Kant, 1991:8). Ancak Kant’a göre birey çoğunlukla kendi çıkarını ön plana alır. Bu görüşünü "her yerde hep ortaya firlayan sevgili bene tosları" diyerek destekler (Kant, 1886:19). Buna karşın o olması gerekenden bahsetmeye devam eder. İnsan kendi iyi amaçlarını gerçekleştirme çabasında olduğu kadar başkalarının iyi amaçlarını da gerçekleştirme peşinde olmalı ve iyiye hizmet etmelidir (Kant, 1886:44). Bireyin belirlediği ilkelerde başka bireyler kendilerini amaç olarak bulmalıdır. Ya da bireyin belirlediği eylemsel ilkeler aynı şekilde başka bireylerin de temel eylemsel ilkeleri olmalıdır (Kant, 1886:51). Bireyin amaç olabilmesini sağlayan tek şart ahlaklılıktır. İnsanlık ve ahlaklılık değerli olan tek şeydir (Kant, 1886:49).

Görüldüğü gibi Kant pratik-rasyonellikte ahlaka büyük önem verir. 0, ahlakın ise 'salt pratik akıl' dediği kaynağa bağlı olduğunu belirtir.

\subsection{Salt Pratik Akıl}

Kant'ın öne sürdüğü salt pratik akıl, tüm dünyevi ve şehvani içgüdülerden münezzeh, tamamıla sorumluluk bilincine sahip bir düzeye işaret eder. Bu akıl tarafından üretilen ve faaliyete geçirilen düşünce ve kararlarda ahlakın en üstün ilkesinin ortaya çıkarılabileceğini söyler. Çünkü salt pratik akıl doğruluğu bilimsel ve deneyimsel araçlarla ispata gerek duyulmadan kabul edilen bilgiyi yasalaştıran akıl düzeyidir (Kant, 2000:137; Hunt, 2002:129).

Kant'ın öne sürdüğü salt pratik akıl onun pratik-rasyonellik tasarımının özünü oluşturur. İyi olanı sadece kendisi iyi olduğu için yapmak salt pratik aklın en güzel eylemidir. Bu akıl aynı zamanda pratik-rasyonel eylemi de inșa eder. Yani pratik-rasyonel eylem, akıl ve ahlakın bütünleșmesini gerektirir. Kant'a göre pratik-rasyonel eylemin kapsadığı ahlakilik sadece akıl sahibi bireylerde vardır (Kant, 1886:12). Bu nedenle pratik-rasyonel eylem aklın öncülügünde tasarlanmalıdır (Kant, 1886:19-20).

\subsection{Ahlakın Üstün İlkesi}

Kant ele aldığı farklı konularda pratik-rasyonellik tasarımına sürekli bir tuğla daha koyar. Bu doğrultuda olmak üzere 0 , ahlakın üstün ilkesini üç farklı zıtlık ilişkisi ile açıklar. Bu ilişkiler ağını ödev ve istek zıtllğı, heteronom ve özerklik zıtlığı, hipotetik buyruk ve kategorik buyruk zıtllğı oluşturur. Birinci ilişki durumuna göre birey ödev kaynaklı eylemsel faaliyetlerde bulunmalıdır. Aksi takdirde Kant, bireyin dünyevi istekler için ne kadar çabalarsa o derece hakiki memnunluktan uzaklaşacağını öne sürer (Kant, 1886: 6). Birey dünyevi amaçları uğruna enerji harcayıp mutluluğu yakaladığını düşünürken aslında bir o kadar da yük edinir (Kant, 1886:7; Regan, 2002:281). Dolayısıyla Kant’a göre eyleme ahlakiliğini kazandıran ilke yalnızca ödev dürtüsüdür.

İkinci zıtlık durumuna göre heteronom eylem, bireyin dışsal faktörlerin yönlendirmesine bağlı olarak yerine getirdiği eylemlerdir. Kant bu eylem türüne karşı çıkar çünkü esas amaç olan insan bu tarz eylemlerde araçsallaştırılan bir şeye dönüşür. Buna karşın özerk eylem olgusu bir şeyi kendisi bir amaçmış gibi yapmak demektir. Düşünüre göre var olan her şey belli yasalara tabi olduğundan insanlar da bir takım yasalara göre hareket eder. Yani insanların eylemleri çeşitli yasalar tarafından motive edilir. $\mathrm{Bu}$ yasaya Kant akıl der. İnsan aklı, kendi iradesini yönlendirip herhangi bir farklı yasanın veya isteklerin dayatmasından soyutlanabilirse özgür tercih yapabilir (Kant, 1886:48-51).

Kant yine aklın iradeyi komuta etmesini açıklamak için hipotetik buyruk ve kategorik buyruk kavramlarını kullanır. Hipotetik buyruk, şart içeren araçsal akıldır. Burada eylemin yapılma amacı bir başka amacı elde etmeye yöneliktir. Karşıt konumda olan kategorik buyruk ise eylemin kendisinin iyi olduğu için yapılmasıdır. Yani herhangi bir koşul içermeden bireyin iyi olanı tercih etmesidir. Düşünüre göre eylemin ahlaksal değerini kategorik buyruk verir (Rawls, 1993:49-50; Rauscher, 1998:414).

Böylelikle Kant, pratik-rasyonelliği akıl ve ahlak sütunları üzerine bina eder. Pratik-rasyonel eylem, akıl ve ahlak süzgecinden geçirilmiş eylemdir. Kant'ın sadece kendi çıkarını düşünen, dünyayı ben merkezli gören ve eylemlerini bu anlayışa göre hesaplayan araçsal akla yoğun tepki gösterdiği fark edilir. Alman düşünür ampirik filozofların ve faydacı düşüncenin karşısına salt pratik aklı öne sürer. Kant'ın felsefesinde birey akılcı ve erdemli davranır, ahlaki değerlere önem verir, iyiyi iyi olduğu için benimser yani pratik-rasyonel eylemde bulunur.

\section{SONUÇ}

Rasyonelleşme ekonomi, siyaset, hukuk, din, bilim, sanat gibi toplumsal hayatın her alanında önem arz eden bir kavramdır. Pek çok türü ve alt başlığı bulunan bu kavrama en iyi alternatif kavram pratikrasyonelliktir. 
Max Weber pratik-rasyonellik olgusunu yalnızca Protestan Etik'le özdeşleştirir. Üstelik Weber dinin rasyonelleşmesi bağlamında pratik-rasyonellik varsayımını olumlarken, bu girişimi diğer değer alanlarında sürdürmek yerine adeta oyunu amaç-rasyonellikten yana kullanır. Bu nedenle Weber'in düşünce dünyasında pratik-rasyonellik hakkı teslim edilmemiş bir proje olarak kalır.

Halbuki Weber rasyonelliğin sadece menfaat odaklı hareket eden seküler bir aklın ürünü olmadığını, materyalist felsefenin popülerlik kazandığı bir dönemde ortaya koyar. 0, pratik-rasyonellik olgusuyla dini ve ahlaki ilkelere dayalı aklın da bu şekilde başarılı olabileceğine işaret eder. Yani rasyonel ve ilkeli şekilde oluşturulan siyasi, ekonomik, mali, hukuki vb. amaçların rasyonel araçlarla ve dini değerlerin esas alınarak gerçekleştirilmesi mümkündür.

Kant'ın pratik-rasyonellik tasarımında hareket noktası ise salt pratik akıldır. Bu akıl düzeyi arı bir şekilde tamamen sorumluluk bilinciyle karar alır ve eylemde bulunur. Sadece kendi faydasını düşünen insan modeline tepki olarak Alman filozof akla önem veren, ahlaklı ve erdemli eylemde bulunan insanı ikame eder. Ayrıca Kant'ın pratik-rasyonelliğinde iyi her zaman yalnızca iyi olduğu için yapılmalıdır.

Anlaşılacağı üzere pratik-rasyonellik kavramına bilhassa günümüz dünyasında çok daha fazla ihtiyaç duyulur. Sosyo-politik kargaşanın hat safhada yașanması ve ekonomik gelişmeye sosyo-kültürel alanın feda edilmesi ile işlevini kaybeden pratik-rasyonellik; post-modern bireyin insani hüviyetine kavuşmasını sağlayabilecek, layık olduğu şekilde yaşamasına imkan oluşturabilecek ve insani ve ilahi değerleri toplumsal bünyede işler hale getirerek toplumsal bütünleşmeyi tesis edebilecek evrensel nitelikte bir olgudur. Para, güç, başarı, haz gibi amaç-rasyonel unsurların değer alanlarını kolonize etmesiyle bugünlerde doruğa tırmanan bireysel ve toplumsal patolojiler, pratik-rasyonellik anlayışının tüm dünya toplumlarında yayılmasına ne kadar çok ihtiyaç olduğunu vurgular niteliktedir. Araçsal ve şeytani aklın egemenliğinin kırılması gerek bireyin iç dünyasının gerekse dünya toplumlarının huzuru, refahı ve özgürlüğü açısından önem arz eder. Çünkü pratik-rasyonellik dinamiklerinin özünde insanın günlük hayatını kolaylaştırma, hayatı ve çevreyi daha yaşanabilir kılma, fayda ve kârı optimum ahlak noktasına çıkarma, toplumsal rızayı ve konsensüsü tesis etme, özgür ve mutlu bireyler yetiştirme, sosyal refahı arttırma, adilane ve barışçıl bir toplum inşa etme gibi idealler yatar. Bu bakımdan insan hayatının, firma organizasyonlarının ve toplumsal sistemlerin pratik-rasyonellik çerçevesinde yeniden inşası üzerinde titizlikle durulmalıdır. Buna ilişkin olarak düşünürlerin birbirinden farklı teorileri olsa da hepsinin özellikle vurguladığı konu toplumun yok olmaya yüz tutmuş organik bağlarının yeniden canlandırılması gerektiğidir. Ünlü Alman düşünürü Jürgen Habermas'ın da dediği gibi İbrahimî dinlerin özünde var olan 'adalet, ahlak, doğruluk, dürüstlük, hoşgörü, sadakat, paylaşma, dayanışma' gibi değerlerin hem bireyler arası hem de kurumsal ilişkilerde motive edici ve düzenleyici unsurlar olarak öne çıkarılmaları gerekir. İnsan her eylemde, etkinlikte, düşüncede ve kararda yeniden bir amaç olmalı ve yaratılmış varlıkların en üstünü olarak değer görmelidir. Bunun için de atılacak adımların hepsi mikro ve makro bazda ilkeleştirilmeli ve içselleştirilmelidir. 


\section{KAYNAKÇA}

Aristotle. (1906), The Nicomachean Ethics of Aristotle, Tenth Edition, Tr. F. H. Peters, London: K. Paul, T. T.

Barker, M. (1980), “Kant as a Problem for Weber”, The British Journal of Sociology, 31(2), 224-245.

Dowie, M. (1977), “Pinto Madness”, Mother Jones, September-October, 2, 18-32.

Duran, B. (2017), Din ve Kapitalizm, Letonya: Lambert Academic Publishing.

Chowers, E. (1995), "Max Weber: The Fate of Homo-Hermeneut in a Disenchanted World", Journal for European Studies, 25(2), 123-40.

Habermas, J. (1989), Toward a Rational Society: Technology and Science as "Ideology", Tr. J. Shapiro, Cambridge: Polity Press.

Habermas, J. (1984), The Theory of Communicative Action Volume 1: Reason and the Rationalization of Society, Boston: Beacon Press.

Harrington, A. (2000), "Value-Spheres or 'Validity-Spheres'?: Weber, Habermas and Modernity”, Max Weber Studies, 1(1), 84-100.

Harsanyi, J. C. (1977), "Morality and the Theory of Rational Behavior", Social Research: Rationality, Choice, and Morality, 44(4), 623-656.

Hunt, L. (2002), "Principle and Prejudice: Burke, Kant and Habermas on the Conditions of Practical Reason", History of Political Thought, 23(1), 117-140.

Jenkins, R. (2000), "Disenchantment, Enchantment and Re-Enchantment: Max Weber at the Millennium", Max Weber Studies, 1(1), 11-32.

Kalberg, S. (1980), “Max Weber's Types of Rationality: Cornerstones for the Analysis of Rationalization Processes in History", The American Journal of Sociology, 85(5), 1145-1179.

Kant, I. (2000), Critique of Pure Reason, Tr. P. Guyer, A. W. Wood, Cambridge: Cambridge University Press.

Kant, I. (1991), The Methaphysics of Morale, Tr. M. Gregor, Cambridge: Cambridge University Press.

Kant, I. (1886), The Metaphysic of Ethics, Third Edition, Tr. J. W. Semple, Edinburgh: T. \& T. Clark.

Laiz, A. M., Schlichte, K. (2016), “Rationality and International Domination: Revisiting Max Weber”, International Political Sociology, 10(2), 168-184.

MacInthyre, A. (1988), Whose Justice? Which Rationality?, Indiana: University of Notre Dame Press.

McLear, C. (2015), "Two Kinds of Unity in the Critique of Pure Reason", Journal of the History of Philosophy, 53(1), 79-110.

Özer, B. (2010), "Commonalities and Differences Between Max Weber and Michael Foucault on the Theme of Rationalization of the Body", Yönetim ve Ekonomi, 17(2), 13-24.

Parsons, T. (1937), The Structure of Social Action: A Study of Social Theory with Special Reference to a Group of Recent European Writers, United States: McGraw Hill Book C.

Philips, M. (1987), "Reason, Dignity and the Formal Conception of Practical Reason", American Philosophical Quarterly, 24 (2), 191 - 198.

Rauscher, F. (1998), "Kant's Two Priorities of Practical Reason", British Journal for the History of Philosophy, 6(3), 397-419.

Rawls, J. (1993), Political Liberalism, New York: Columbia University Press.

Reckling, F. (2001), "Interpreted Modernity Weber and Taylor on Values and Modernity", European Journal of Social Theory, 4(2), 153-176.

Regan, D. H. (2002), "The Value of Rational Nature", Ethics, 112(2), 267-291.

Ritzer, G. (1975), "Professionalization, Bureaucratization and Rationalization: The Views of Max Weber", Social Forces, 4(53), 627-634.

Roth, G. (1976), "History and Sociology in the Work of Max Weber", The British Journal of Sociology, 3(27), 306-318. 
Rutgers, M. R., Schreurs, P. (2006), “The Morality of Value and Purpose Rationality: The Kantian Roots of Weber's Foundational Distinction”, Administration \& Society, 38(4), 403-421.

Tenbruck, F. H. (1980), "The Problem of Thematic Unity in the Works of Max Weber", The British Journal of Sociology, 3(31), 316-351.

Weber, M. (2013), The Agrarian Sociology of Ancient Civilizations, Tr. R. I. Frank, London \& New York: Verso.

Weber, M. (1978), Economy and Society, Ed. G. Roth And C. Wittich, California: University of California Press.

Weber, M. (1968), The Religion of China, Ed. G. Roth And C. Wittich, Tr. H. H. Gerth, Ny: The Free Press.

Weber, M. (1965), The Sociology of Religion. Tr. E. Fischoff, Boston: Beacon Press.

Weber, M. (1947), The Theory of Social and Economic Organization, Tr. A. M. Henderson and T. Parsons, London: William Hodge and Company Press.

Weber, M. (1946a), Politics as a Vocation: From Max Weber: Essays in Sociology, Ed. Gerth, H. H. and Mills, C. W., Ny: Oxford University Press.

Weber, M. (1946b), The Social Psychology of the World Religions: From Max Weber: Essays in Sociology, Ed. Gerth, H. H. and Mills, C. W., Ny: Oxford University Press.

Weber, M. (1950a), The Protestant Ethic and the Spirit of Capitalism, Third Impression. Tr. Talcott Parsons, New York: Charles Scripner's Son.

Weber, M. (1950b), General Economic History, Tr. F. H. Knight, Illinois: The Free Press.

Wilson, H. T. (2002), "Rationality and Capitalism in Max Weber's Analysis of Western Modernity”, Journal of Classical Sociology, 2(1), ss. 93-106.

Yee, A. S. (1997), “Thick Rationality and the Missing 'Brute Fact': Limits of Rationalist Interpretation of Norms and Ideas”, Journal of Politics, 59(4), 1001-1059. 